\title{
Evaluation of Injuries Involving Exposure to Blood and Body Fluids Among Hospital Healthcare Workers
}

\author{
Hastanemiz Çalışanlarında Kan ve Vücut Sıvılarına Maruziyeti Içeren Yaralanmaların \\ Değerlendirilmesi
}

\author{
Handan ALAY', Melek ŞAHINER², Neslihan ÇELiK ${ }^{3}$, Berrin GÖKTUĞ KADIOĞLU ${ }^{4}$ \\ ${ }^{1}$ Nenehatun Maternity Hospital, Clinic of Infectious Diseases and Clinical Microbiology, Erzurum, Turkey \\ ${ }^{2}$ Nenehatun Maternity Hospital, Unit of Infection Control, Erzurum, Turkey \\ ${ }^{3}$ Regional Training and Research Hospital, Clinic of Infectious Diseases and Clinical Microbiology, Erzurum, Turkey \\ ${ }^{4}$ Nenehatun Maternity Hospital, Clinic of Obstetrics and Gynecology, Erzurum, Turkey
}

\section{Abstract}

Introduction: Injuries involving exposure to blood and body fluids are among the risks that healthcare staff frequently encounter. In this study, injuries that occurred in Nenehatun Obstetrics Hospital from January 2011 to May 2016 were evaluated and preventive measures to reduce injuries among healthcare workers are presented.

Materials and Methods: "Staff Injury Forms" recorded by the hospital Infection Control Committee (ICC) between January 2011 and May 2016 in Nenehatun Obstetrics Hospital were retrospectively assessed. In addition, a survey concerning blood and body fluid exposure in the last five years was conducted among the 180 staff members who could be reached from a total of 252 healthcare personnel. Data were analyzed using SSPS v.15.0 (SPSS Inc, Chicago, Illinois, USA) data analysis system.

Results: Of 38 cases reported to the ICC, $18 \%(n=7)$ of the employees were male and $82 \%(n=31)$ were female. Only $2.63 \%$ involved mucosal contact with blood and body fluid exposure, the remaining $97.3 \%$ were percutaneous sharp object injuries. Analysis of the survey data revealed that $0.5 \%$ of the injuries consisted of exposure to blood and body fluids and $26.4 \%$ consisted of percutaneous injuries. According to ICC data, $72.9 \%$ were needlestick injuries. The group of healthcare workers injured most often was cleaning staff according to ICC data (31.5\%) and doctors and nurses according to the survey data (24.5\%). Injuries mostly took place in delivery room according to ICC data; however, survey results indicated that injuries mostly occurred in the surgery room. According to the investigation of immunity status of 38 healthcare staff, all were negative for anti-HCV and anti-HIV; while $92.1 \%(n=35)$ were found positive for anti-HBs and $7.9 \%(n=3)$ were negative for anti-HBs. Of the source patients of the blood or body fluid, $10.5 \%(n=4)$ were positive for HBsAg, 2.6\% $(n=1)$ were positive for anti-HBs, and $71 \%(n=27)$ were negative for anti-HBs. Seroconversion was not detected in any of the cases.

Conclusion: In addition to standard infection control measures, the occupational hazards faced by healthcare workers can be decreased by providing immunity against vaccine-preventable diseases, eliminating problems concerning staff recruitment, improving usage of safe medical instruments, implementing continuous employee training, and repeating training to increase the quality and awareness of the staff.

Keywords: Needle stick and sharp injury, infection, vaccine rejection, HIV, HBV

\section{Öz}

Giriş: Kan ve vücut sıvılarına maruziyeti içeren yaralanmalar sağlık çalışanlarının sıklıkla karşılaşmakta olduğu risklerdendir. Çalışmada Erzurum Nenehatun Kadın Doğum Hastanesi'nde Ocak 2011-Mayıs 2016 tarihleri arasında meydana gelen yaralanmalar incelendi ve yaralanmalara ilişkin alınabilecek önlemler sunuldu.

Gereç ve Yöntem: Erzurum Nenehatun Kadın Doğum Hastanesi'nde Ocak 2011-Mayıs 2016 tarihleri arasında enfeksiyon kontrol birimince kayıtları tutulan "Çalışan Yaralanma Formları" retrospektif olarak değerlendirildi ve eş zamanlı olarak 2016 yılı Mayıs ayı içerisinde hasta ile teması olan 252 sağlık çalışanından ulaşabildiğimiz 180 kişiye, son 5 yıl içerisinde kan ve vücut sıvılarına maruziyeti içeren yaralanmalarının sorgulandığı anket sonuçları SPSS v.15.0 (SPSS Inc, Chicago, Illionis, ABD) paket programı ile değerlendirildi. 
Bulgular: Enfeksiyon Kontrol Komitesi'ne (EKK) başvuran 38 olgunun \%18'i $(n=7)$ erkek, \%82'si $(n=31)$ kadındı. Yaralanmaların yalnızca \%2,6'sı kan ve vücut sıvılarına maruziyeti içeren mukozal temas iken, kalan \%97,3 olgu kesici delici aletler ile gerçekleşen perkütan yaralanmalar olarak tespit edildi. Anket verilerinin değerlendirilmesi neticesinde \%0,5 oranla kan ve vücut sıvılarına maruziyeti içeren mukozal temas ve \%26,4 oranla perkütan yaralanma saptandı. EKK verilerine göre yaralanmaların \%72,9'u iğne ucu yaralanmalarıydı. EKK verilerine göre en çok yaralanmaya maruz kalan meslek grubu \%31,5 oranla temizlik personeli iken anket verilerine göre bu grubu \%24,5 oran ile doktor ve ebeler oluşturuyordu. En çok yaralanma yaşanan birim EKK verilerine göre doğum salonu iken anket verilerine göre ameliyathane olarak tespit edildi. Otuz sekiz sağlık çalışanının bağışıklık durumları incelendiğinde olguların tamamında anti-HCV ve anti-HIV değerleri olumsuz, \%92'si ( $n=35$ ) anti-HBs olumlu, \%7,9'u ( $n=3$ ) anti-HBs olumsuzdu. Temasa maruz kalınan hastaların ise \%10,5'i $(n=4)$ HBsAg olumlu, \%2,63'ü $(n=1)$ anti-HBs olumlu ve \%71'inin $(n=27)$ anti-HBs olumsuz olduğu saptandı. Olgularda serokonversiyon saptanmadı.

Sonuç: Standart enfeksiyon kontrol önlemlerinin yanında sağlık çalışanlarının aşı ile korunabilecekleri hastalıklara karşı bağışıklamasının sağlanması, personel istihdamında yaşanan sıkıntıların giderilmesi, güvenli tıbbi gereç kullanımlarının geliştirilmesi, hizmet içi eğitimlerin devamlılı̆̆ ve yapılan eğitimlerin kalitesinin çalışanların farkındalığını artırıcı şekilde gözden geçirilmesinin, sağlık çalışanlarının karşılaştığı riskleri azaltmada yararlı olacağını düşünmekteyiz.

Anahtar Kelimeler: Kesici delici alet yaralanmaları, enfeksiyon, aşı reddi, HIV, HBV

\section{Introduction}

Healthcare workers are exposed to many occupational hazards, the foremost being contact with infectious materials. Contact with infectious materials can be defined as splashes and percutaneous injuries that expose an individual to blood and body fluids. Viral hepatitis and 'Human immunodeficiency virus' (HIV)/acquired immunodeficiency syndrome (AIDS) are foremost among the infections that can be transmitted through blood and body fluids. The risk of horizontal and nosocomial transmission of these infections is becoming a current issue of increasing importance in Turkey[1]. It is estimated that approximately 1-2 million people die of complications related to hepatitis $B$ virus (HBV) and 3 million healthcare workers are exposed to bloodborne pathogens through percutaneous injuries every year[2]. The most effective prevention of HBV infection, which has high mortality and morbidity, is immunization[3].

Studies have shown that HIV is transmitted at a lower rate than HBV in injuries with cutting and penetrating objects (sharps) [4]. The depth of the injury and the presence of visible blood on the object are factors that increase the risk of infection with HIV, while the use of protective equipment reduces the risk of infection[1]. The risk of HIV transmission due to percutaneous injury with HIV-infected material is $0.3 \%$, whereas this rate reaches approximately $31 \%$ with $\mathrm{HBV}$ exposure. The risk of infection due to HCV exposure is 1.8\%. Anti-HCV testing of blood donors has greatly reduced HCV transmission in Turkey[5]. In clinical practice, transmission from a carrier healthcare worker to the patient is possible, but it is 10 times more likely for transmission to occur from a patient to a healthcare worker[1]. The risk of infection following injuries involving contact with blood and body fluids is determined by the type of pathogen, the type of contact, the amount of blood contacted, and the amount of virus present in the patient's blood at the time of contact[6]. In light of this information, it is clear that healthcare workers face significant occupational hazards, and in spite of taking all precautions possible, it is impossible to eliminate these risks due factors such as lack of professional experience, intensive work pace, inadequate staff numbers, and carelessness due to long night shifts $[7,8]$.

This study discusses the risks faced by healthcare workers and examines the knowledge and their attitudes concerning injuries involving exposure to blood and body fluids, and what measures can be taken to address this problem.

\section{Materials and Methods}

\section{Study Design}

This retrospective study was conducted by analyzing Employee Health Follow-up forms used for percutaneous sharp/needlestick injuries and injuries involving exposure to blood and body fluids filed between January 2011 and May 2016 by the Infection Control Committee (ICC) of the Erzurum Nenehatun Maternity Hospital. The hospital employs an average of 450 healthcare workers, performs 8,396 births, and serves 164,590 patients annually. The study were approved by the Ataturk University of Local Ethics Committee (Protocol number: B.30.2.ATA.0.01.00/167).

\section{Study Procedure}

Our analysis included the HBsAg, anti-HBs, anti-HCV, and antiHIV serology (Roche Cobas e.600, Roche Diagnostics, Switzerland) test results of the injured healthcare workers obtained during follow-up and, if known, of the source patient. We analyzed injury rates by year, the units in which the injured employees worked (delivery room, gynecology department, operating room, neonatal intensive care, phlebotomy unit, emergency department, laboratories, medical waste unit, postpartum unit and cesarean unit), rates of personal protective equipment usage, relation of the injury to waste management, distribution of injured staff by occupation (physician, midwife, nurse, cleaning staff, intern 
and health technician), immunity status, and the distribution of objects causing injury. We also evaluated the last 5 years of data from the Staff Health Screening Follow-up forms. At the same time, a survey was conducted on healthcare workers' knowledge of and attitudes toward injuries involving exposure to blood and body fluids. Of the 252 healthcare workers who had contact with patients at the hospital, we were able to contact and administer the questionnaire to 180 . The employees were asked about their units, their duties, whether they had received training on injuries involving exposure to blood and body fluids, whether they had had any injuries involving exposure to blood and body fluids within the last 5 years, and if so, the object that caused the injury, their attitude after the injury, whether they consulted the ICC, and if not, their reason for not consulting the ICC.

\section{Data Analysis}

Data obtained from the Employee Health Follow-up forms filed with the ICC were evaluated in terms of number and percentage. The SPSS v.15.0 (SPSS Inc., Chicago, Illinois, USA) software package was used for statistical analysis of the survey results. The results were compared with the ICC reports.

\section{Results}

\section{Demographic Characteristics of the Participants}

A total of 38 healthcare workers who had consulted the ICC due to injury involving exposure to blood and body fluids between January 2011 and May 2016 were evaluated. The mean age of the 38 healthcare workers was 33 years; $18 \%(n=7)$ were male and $82 \%(n=31)$ were female. Only $2.6 \%(n=1)$ of the injuries were mucosal exposure to blood and body fluids, while the remaining 97.3\% ( $n=37)$ were percutaneous sharp object injuries. In the survey study conducted to evaluate healthcare workers' knowledge and attitudes pertaining to injuries involving exposure to blood and body fluids, $0.5 \%(n=1)$ of the 180 responders stated that they had been exposed to blood and body fluids via mucosal contact, and 26.4\% $(n=48)$ stated that they had experienced a percutaneous sharps injury.

\section{Distribution by Occupational Group}

Analysis of the occupations of healthcare workers who reported injuries involving exposure to blood and body fluids to the ICC showed that the group most injured was the cleaning staff $(31.5 \%, n=12)$, followed by nurses $(26.3 \%, n=10)$, midwives $(26.3 \%, n=10)$, interns $(7.89 \%, n=3)$, doctors $(5.26 \%, n=2)$, and laboratory technicians $(2.63 \%, n=1)$. In contrast, the survey data indicated that the occupational distribution of injuries involving exposure to blood and body fluids was led by doctors $(24.5 \%$, $n=12)$, followed by midwives $(24.5 \%, n=12)$, cleaning staff $(22.4 \%, n=11)$, nurses $(20.4 \%, n=10)$, and health technicians $(8.2 \%, n=4)$ (Figure 1).

\section{Injury Incidence}

When injuries were assessed according to hospital unit, the delivery room had the highest incidence of injury, with 26.3\% $(n=10)$ of the reported cases according to ICC data. This was followed by the gynecology unit at $23.6 \%(n=9)$, the operating room at $21 \%(n=8)$, and the neonatal intensive care unit at $13.15 \%$ $(n=5)$. According to the results of our survey, the operating room had the highest incidence of injuries at $40 \%(n=19)$, followed by the neonatal intensive care unit at 20\% $(n=10)$ (Figure 2).

\section{Manner of Injury}

Analysis of the types of sharp medical instruments that caused injuries in the cases who consulted the ICC showed that the majority of injuries were caused by needle stick $(72.9 \%, n=27)$, followed by suture needles $(18.9 \%, n=7)$. The distribution of sharp causative objects according to the survey data showed needles first $(77.55 \%, n=38)$, followed by scalpels $(14.2 \%, n=7)$ (Figure 3).

Thirty-three percent of needle-stick injuries were related to recapping the needles according to ICC data, whereas only

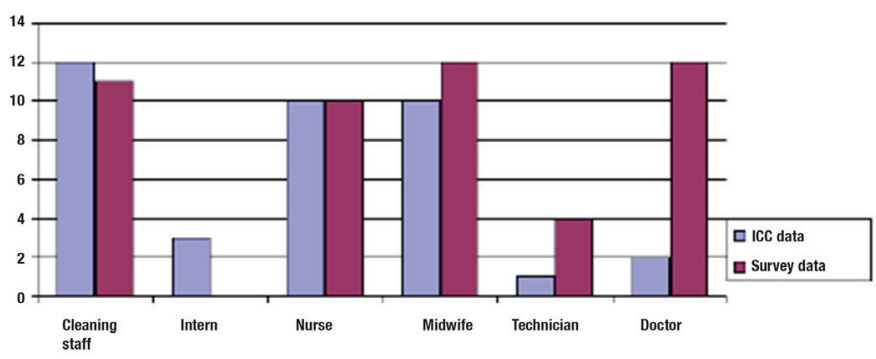

Figure 1. Distribution of injuries according to occupational group ICC: Infection Control Committee

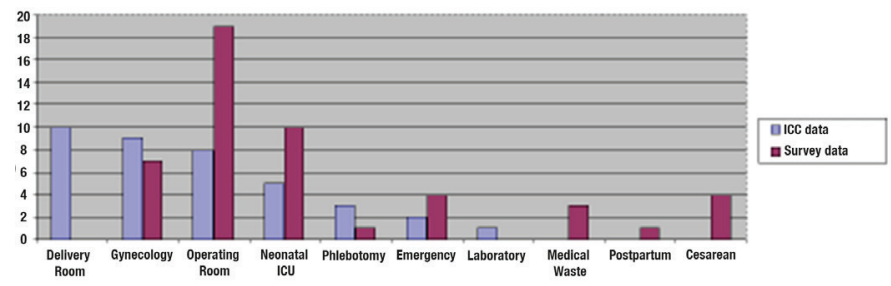

Figure 2. Distribution of injuries according to hospital unit ICC: Infection Control Committee, ICU: Intensive care unit

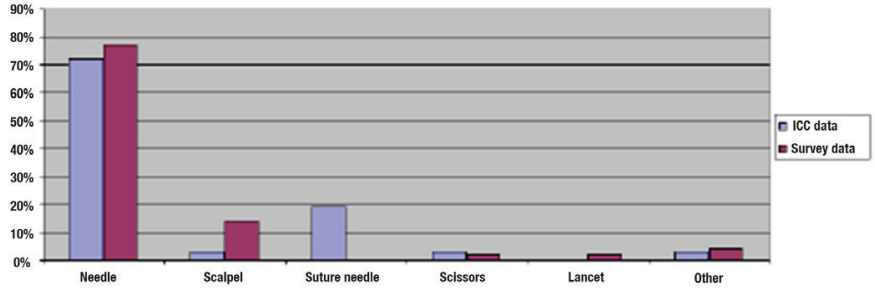

Figure 3. Distribution of injuries according to causative object ICC: Infection Control Committee 
$18.37 \%$ of needle-stick injuries reported by survey occurred while recapping the needle (Figure 4).

Thirty-four percent $(n=13)$ of the 38 injuries reported to the ICC were related to improper waste management. Some of these accidents occurred during medical waste collection, and some occurred due to improper separation of waste materials during cleaning. According to our survey results, we found that $28.57 \%$ $(n=14)$ of injuries took place during surgery, $18.37 \%(n=9)$ while recapping the needle, $14.29 \%(n=7)$ while drawing blood, $10.20 \%$ $(n=5)$ during cleaning, and $10.20 \%(n=5)$ during waste collection (Figure 4).

\section{Protective Equipment Use}

When we looked at rates of personal protective equipment usage, we found that $78 \%(n=29)$ of healthcare workers used gloves according to ICC data and that $98 \%(n=48)$ used gloves according to survey data. In this study, hand and finger injuries accounted for 37 of the 38 cases reported to the ICC, and it was determined that gloves were not worn in about $22 \%(n=8)$ of these injuries.

Mucosal exposure to blood and body fluids occurred in only one case, when blood splashed into the healthcare worker's eye during surgery in the operating room, and we determined that goggles were not worn as personal protective equipment at that time.

Reasons for Not Reporting Injuries to the Infection Control Committee

Of the $27.22 \%(n=49)$ of the workers who responded on the
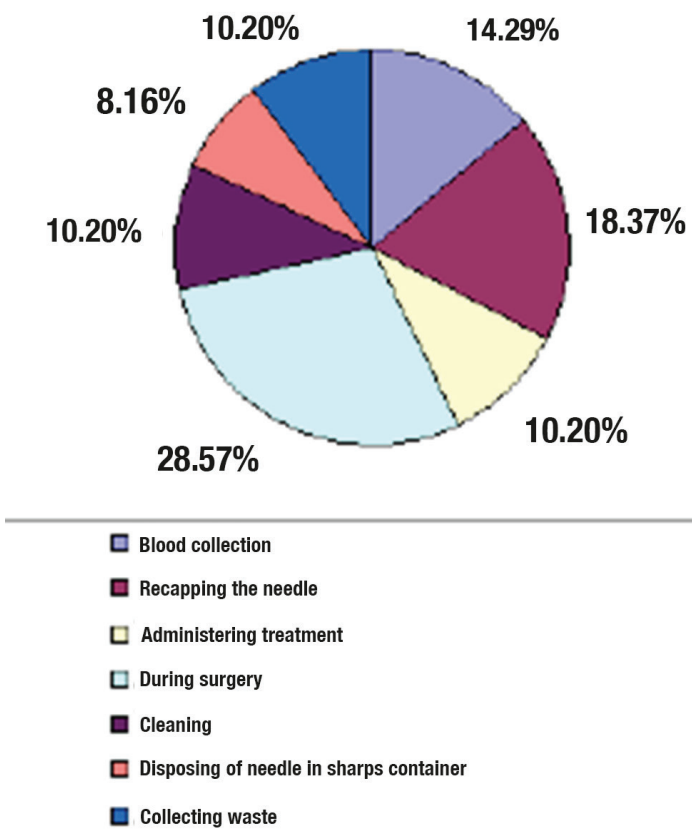

Figure 4. Context of needlestick injuries according to survey responses survey that they had sustained injuries involving exposure to blood and body fluids, only 48.98\% $(n=24)$ reported their injury to the ICC. The most common reason stated for not reporting their injuries to the ICC was not having time due to being very busy $(20 \%, n=5)$, followed by not finding it necessary, the source patient not having a contagious disease, and the wound not being very deep (16\%, $n=4$ for each). Twelve percent $(n=3)$ of the injured healthcare workers described the injury as insignificant (Figure 5).

In terms of the healthcare workers' knowledge and attitudes pertaining to injuries involving exposure to blood and body fluids, $94.44 \%$ (170) of healthcare workers stated in the survey that they had received training on the subject.

\section{Serological Results}

According to ICC records of the immune status of the 38 healthcare workers who reported injuries between January 2011 and May 2016, the anti-HCV and anti-HIV serology results of all cases were negative, $92 \%(n=35)$ were anti-HBs positive, and $7.9 \%(n=3)$ were anti-HBs negative. Of the source patients involved in the incidents, $10.5 \%(n=4)$ were $\mathrm{HBsAg}$ positive, one $(2.63 \%)$ was anti-HBs positive, and $71 \%(n=27)$ were anti-HBs negative. The source patient could not be identified in $15.78 \%$ $(n=6)$ of the reported incidents. In all injuries for which the source patient could not be determined, the anti-HBs serological results of the healthcare workers were positive. Three doses of hepatitis $B$ vaccine were administered to two healthcare workers who were exposed to injury and was negative for anti-HBs. One
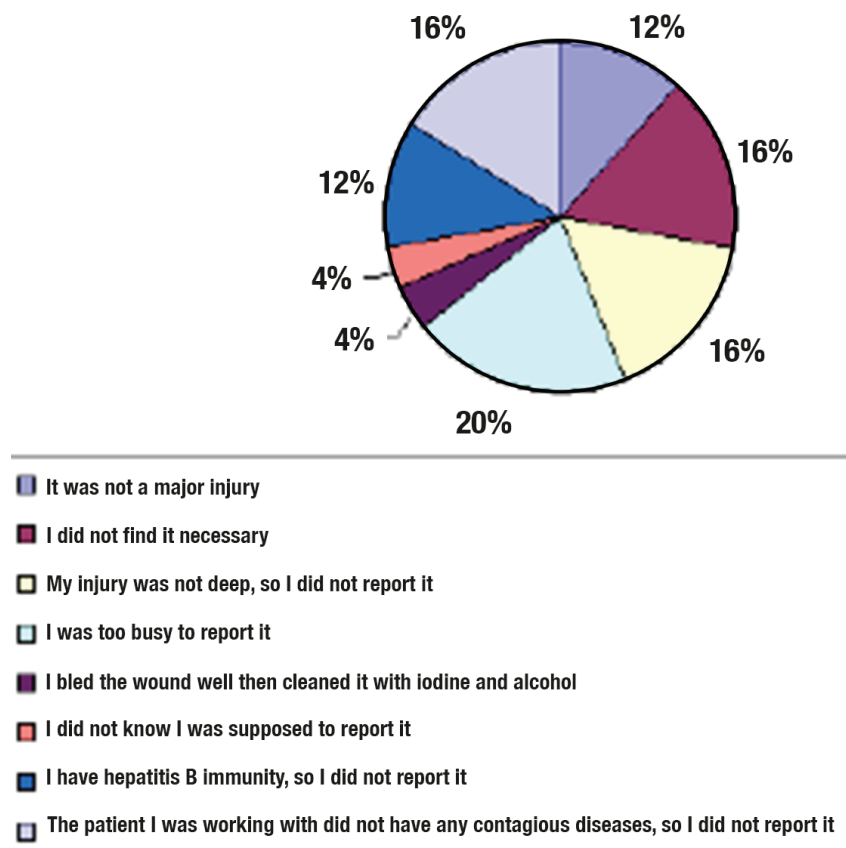

Figure 5. Survey data regarding reasons for not reporting injuries involving exposure to blood and body fluids to the hospital Infection Control Committee 
healthcare worker who tested negative for anti-HBs refused to be vaccinated despite ICC recommendation because the HBV markers of the source patient were negative. No seroconversion was observed during the 6-month follow-up period.

We also evaluated data from the last 5 years of Staff Health Screening forms filed by the hospital ICC. The hospital provides a large extent of the region's maternity and neonatal intensive care services, with an average of 450 healthcare workers each year. Our analysis showed that $1.1 \%(n=5)$ of the staff were $\mathrm{HBsAg}$ positive, $35.11 \%(n=158)$ had received primary immunization with HBV vaccination, $0.8 \%(n=4)$ had refused immunization with HBV vaccination, and the remaining $62.9 \%(n=283)$ of the staff were anti-HBs positive, with negative anti-HCV and antiHIV serology.

\section{Distribution of Injuries by Year}

Of the reported injuries involving exposure to blood and body fluids in our hospital, 3 occured in 2011, 7 each year in 2012, 2013, and 2014, 11 in 2015, and 3 in 2016 (January-May). The increase in the number of notifications over the years demonstrates that the training provided to healthcare workers on injuries involving exposure to blood and body fluids have increased awareness among the staff (Figure 6).

\section{Discussion}

This study was conducted in a hospital that employees approximately 450 healthcare workers, performs 8,396 births, and serves 164,590 patients annually. Considering the number of reported injuries involving exposure to blood and body fluids occurring between January 2011 and May 2016, it can be assumed that the majority of hospital staff did not report their injuries to the ICC. This problem has been mentioned in various studies[9-12]. The assumption is further supported by the results of our survey

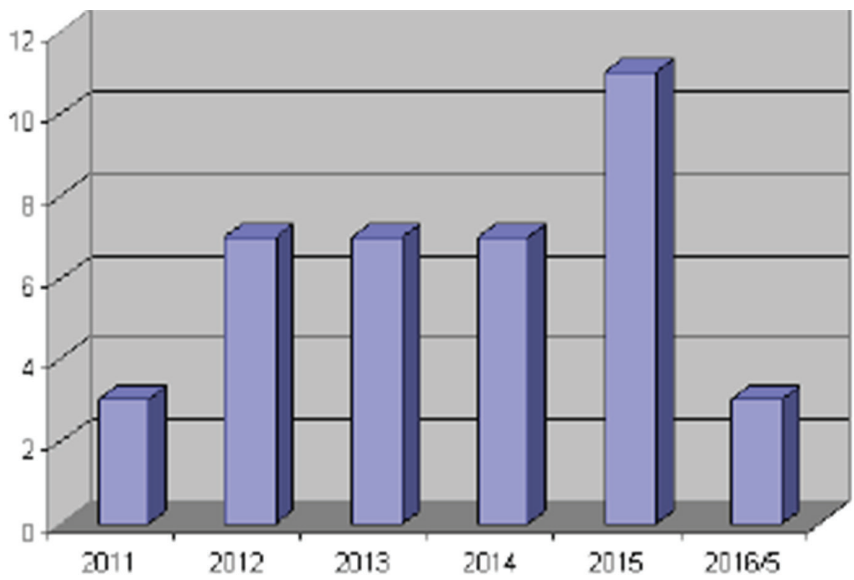

Figure 6. Yearly distribution of injuries involving exposure to blood and body fluids according to hospital Infection Control Committee data conducted with 180 of the 252 healthcare workers who are in contact with patients at the hospital, which indicated that 51\% $(n=25)$ of the injured employees did not notify the ICC.

The probable cause of the underreporting of injuries involving exposure to blood and body fluids is that these injuries are dismissed as unimportant. According to our survey, 25 of the 49 injured healthcare workers did not notify the ICC, suggesting that healthcare workers disregard their injuries for various reasons. Although $94.44 \%$ of survey respondents stated that they had received training on the subject, $51 \%$ of them did not report their injuries to the ICC, revealing that new efforts are needed to increase the effectiveness of training and the awareness. In addition to providing training to all units, it may be useful to post banners and posters emphasizing the importance of sharp object injuries, especially in units with higher patient load and work load and more occupational injuries.

According to ICC data, it was determined that about $31 \%$ of cleaning staff were injured due to inappropriate separation of medical waste during cleaning. Eight percent $(n=3)$ of the staff who reported injuries to the ICC were medical waste collection staff. Our survey results showed that $10.20 \%(n=5)$ of the injured staff were injured during medical waste collection and $8.16 \%$ $(n=4)$ of the reported injuries occurred while throwing waste into sharps containers. This indicates that waste management guidelines are not being followed.

Studies have shown that needle-sticks are the leading cause of sharp object injuries $[7,10,11,13,14]$. In our study, needles were involved in most $(72.9 \%, n=27)$ of the injuries reported to the ICC, and 33\% ( $n=9)$ of these injuries occurred during needle recapping. Our results are consistent with those of Kaya et al.[1], who reported that $93 \%$ of reported injuries were percutaneous, and $50.6 \%$ of these occurred during the needle recapping. In another study, the majority of exposures were mucosal contact due to splashes (60.3\%), followed by needle-stick injuries (28.7\%) [15]. In addition, according to our survey data, needles were the leading medical instrument causing injuries $(77.55 \%, n=38)$, which corroborates the results of other similar studies. The habit of needle recapping, patient density due to high birth rates in our region, difficulties with staff recruitment $[16,17]$, sudden reflex movements and agitation of patients during suturing, and inappropriate waste management can be cited as occupational factors leading to needle-stick injuries.

As in numerous studies from other countries[15,18], Bozkurt et al.[7] determined that nurses were the occupational group at greatest risk of injury in Turkey. However, in our study the cleaning staff received the most injuries, similar to the findings of Merih et al.[13], followed by nurses and midwives. In our survey study, the most injured occupational group comprised doctors and midwives, followed by nurses. Some studies have shown 
that about $60 \%$ of sharp/needlestick injuries are not reported, and reports filed with our ICC show that only 5.2\% $(n=2)$ of doctors made notifications[9-12,18]. According to previous studies, underreporting occurs at a rate of $22 \%$ to $82 \%[19-21]$. The source patient was HBsAg positive in one of the two reported injuries suffered by doctors, suggesting that doctors only notified the ICC for suspicious cases. Our survey results also support this inference. Despite our survey indicates that doctors constituted the most injured group $(n=12)$, the fact that only 2 doctors reported their injuries to the ICC shows that doctors have low awareness of this issue. Reasons cited for not notifying the ICC of injuries were heavy work load $(20 \%, n=5)$ and finding it unnecessary, the source patient not having a contagious disease, and the injury being superficial ( $16 \%, n=4$ for each). The fact that $27.2 \%$ $(n=49)$ of the 180 healthcare workers surveyed were exposed to blood and body fluids once again highlights the significance of occupational hazards.

Considering that percutaneous injuries constitute a major risk for the transmission of infections, the importance of using personal protective equipment once again comes to the fore. The use of gloves reduces the risk of transmission of infectious agents[2]. In a study by Altıok et al.[11], 80\% of nurses used gloves, while Merih et al.[13] found that gloves were used by $57.5 \%$. Nouetchognou et al.[15] determined that 7.3\% of employees exposed to blood and body fluids generally did not use gloves, and that $84.1 \%$ of those with mucosal contact due to splashes did not use protective equipment for the face or eyes. In our study, the protective equipment usage rate was 78\% and the only equipment used was gloves. In only one case, there was mucosal contact due to splash, and we found that protective equipment for the face or eyes was not in use at the time of the accident. Personal protective equipment usage rates should be increased by raising healthcare workers' awareness through in-service training on the prevention of hospital infections. In addition, this training should draw attention to the need to use not only gloves, but also protective equipment for the face and eyes in surgical units, operating theaters, and delivery rooms, where the likelihood of blood and body fluid splashes is higher.

The role of immunization in the prevention of injury-related complications is of crucial importance in terms of both community health and patient and employee safety. A hepatitis $B$ vaccination program has been in practice in Turkey since 1998 within the framework of the Extended Immunization Program (EIP) and encompasses the vaccination of infants, adolescents, and risk groups. Worldwide, 158 countries have included hepatitis $B$ vaccination in their national immunization programs [22]. In our study, 92\% of the 38 healthcare workers who reported injuries had immunity against HBV. When we looked at the rate of vaccination against HBV infection among our hospital staff within the last 5 years, we found this rate to be $35.11 \%$
( $n=158)$. According to World Health Organization estimates, the scope of immunization ranges from 18\% (in Africa) to 77\% (in Australia and New Zealand)[23]. In some studies, the vaccination rate has been reported as $36.6 \%[15]$ and $56 \%[14]$. The rate of $35.11 \%(n=158)$ seen in our hospital was considered close to World Health Organization estimates and it is apparent that more extensive work is needed to ensure the eradication of HBV. Refusal of vaccination is one of the main obstacles to achieving this objective. Considering that community health has a direct impact on world health, the vaccination of all people, especially children and adolescents, is crucial to eradicate vaccinepreventable communicable diseases. It was also expressed in the 19th National Public Health Conference that vaccination refusal has become a major problem in our country and around the world in recent years. A study conducted in Turkey reported vaccination refusal by 764 individuals in a district with a target population of 4,159 . This rate of vaccination rejection is very alarming. News reports in the media have a considerable influence on those who decide to refuse vaccination[24]. The seriousness of this situation is illustrated by the increasing number of child and adult measles cases documented in recent years in some countries including Turkey, particularly in direct proportion to the increase in the number of immigrants[25]. It must not be forgotten that as long as there is no evidence-based reason for the widespread rejection of a certain vaccine, the widespread rejection of other vaccines is inevitable. Therefore, although vaccination campaigns are conducted continuously in our country, they are not sufficient. The fact that it is legal in Turkey for families to give consent for vaccination refusal makes it difficult for the EIP to reach its objectives. Creating public service ads that raise public awareness, integrating vaccine tracking systems through a common national database, and safeguarding the health of future generations with legal regulations may be beneficial to reduce vaccine rejection and reach EIP objectives.

In order to prevent and control infections at our hospital, training regarding hand hygiene, proper use of personal protective equipment, injuries involving exposure to blood and body fluids, and health screenings are provided to all new employees. The immune status of employees is monitored annually and vaccination programs are carried out when deemed necessary. Inappropriate waste management is identified during periodic visits to all units and regulatory and preventive activities are organized. Importance is placed on the provision of safe medical devices; in particular, medical equipment that prevents needlestick injuries (blood collection kits with safety mechanisms) is used in units with high patient load such as the phlebotomy unit.

A limitation of this study is that there were few injuries reported to the ICC due to underreporting, while the number of survey respondents was much higher; therefore, the degree of significance could not be calculated for comparison of the 
entire study population. Furthermore, we could not assess the results of our regulatory and preventive activities. In the future, comparisons can be made with our existing data.

\section{Conclusion}

Measures which will help prevent injuries involving exposure to blood and body fluids include increasing measures to protect healthcare workers and patients, actively encouraging the safe use of medical devices, providing hospital units with appropriate sharps waste containers, following waste management guidelines, eliminating problems with staff recruitment in busy units, scheduling shifts so as to prevent fatigue-related lapses of attention, providing continuous training in infection control, and monitoring staff use of personal protective equipment and vaccination.

\section{Ethics}

Ethics Committee Approval: The study were approved by the Ataturk University Local Ethics Committee (Protocol number: B.30.2.ATA.0.01.00/167).

Informed Consent: Not needed an informed consent form.

Peer-review: Externally and internally peer-reviewed.

\section{Authorship Contributions}

Surgical and Medical Practices: B.G.K., H.A., M.Ş., N.Ç., Concept: H.A., Design: H.A., Data Collection or Processing: M.Ş., Analysis or Interpretation: N.Ç., Literature Search: B.G.K., H.A., N.Ç., Writing: H.A.

Conflict of Interest: No conflict of interest was declared by the authors.

Financial Disclosure: The authors declared that this study received no financial support.

\section{References}

1. Kaya Ş, Baysal B, Eşkazan AE, Çolak H. Evaluation of Sharp Objects Injuries in the Health Care Personnel Working in the Diyarbakir Training and Research Hospital. Viral Hepat J. 2012;18:107-10.

2. Palabıyıkoğlu I. Hastane kaynaklı viral enfeksiyonlar. Topcu AW, Söyletir G, Doğanay M. Enfeksiyon hastalıkları ve mikrobiyolojisi. 3. Baskı Nobel Tıp Kitapevleri. 2008:604-13.

3. Çetinkaya F, Naçar M, Ünalan D, Erkorkmaz Ü, Öztürk Y. The Perceived Risk of Hepatitis B on Assistant Doctors, Intern Doctors, Nurses and Laboratory Technicians. Hastane İnfeksiyonları Dergisi. 2000;4:112-8.

4. Özvarış ŞB. Sağlık çalışanlarının enfeksiyonlardan korunması. Available from: http://www.ttb.org.tr/STED/sted1299/st12994.html Sürekli Tıp Eğitimi Dergisi. 1999;12.

5. U.S. Public Health Service. Updated U.S. Public Health Service Guidelines for the Management of Occupational Exposures to HBV, HCV, and HIV and Recommendations for Postexposure Prophylaxis. MMWR Recomm Rep. 2001;50:1-52.

6. Bolyard EA, Tablan OC, Williams WW, Pearson ML, Shapiro CN, Deitchman SD, The Hospital Infection Control Practices Advisory Committee. Guideline for infection control in health care personnel, 1998. Am J Infect Control. 1998;26:289-354.

7. Bozkurt $S$, Kökoğlu ÖF, Yanıt F, Kocahasanoğlu U, Okumuş $M$, Sucaklı MH Güler S, Kuzhan N, Savrun A, Uçmak H.Needle sticks and injuries due to surgical instruments in health care providers. Dicle Med J. 2013;40:449-52.

8. Samancıoğlu S, Ünlü D, Durmaz AA. The Evaluation of Needlestick and Sharp Injuries Among Intensive Care Nurses. Anadolu Hemşirelik ve Sağlık Bilimleri Dergisi. 2013;16:43-9.

9. Özdemir EG, Şengöz G. The Outcomes of the Attitude and Information Level Questionnaire-Survey on Sharps Injuries in a 500-bed Training and Research Hospital. Med Bull Haseki. 2013;51:11-4.

10. Gücük M, Karabey S, Yolsay N, Özden YI. Percutaneous Injuries in the Health Care Personnel Working in the General Surgery Clinics of the Medical School of İstanbul. Hastane İnfeksiyonları Dergisi. 2002;6:72-81.

11. Altıok M, Kuyurtar F, Karaçorlu S, Ersöz G, Erdoğan S. Healthcare Workers Experiences with Sharps and Needlestick Injuries and Precautions They Took When Injuring. Maltepe Üniversitesi Hemşirelik Bilim ve Sanatı Dergisi. 2009;2:70-9.

12. Patterson JM, Novak CB, Mackinnon SE, Elis RA. Needlestick Injuries Among Medikal Students. Am J Infect Control. 2003;31:226-30.

13. Merih YD, Kocabey MY, Çırpı F, Bolca Z, Celayir AC. Epidemiology and preventive measures of sharps injuries in a state hospital during the last three years. Zeynep Kamil Tıp Bülteni. 2009;40:11-5.

14. Markovic-Denic L, Maksimovic N, Marusic V, Vucicevic J, Ostric I, Djuric D. Occupational Exposure to Blood and Body Fluids among Health-Care Workers in Serbia. Med Princ Pract. 2015;24:36-41.

15. Nouetchognou JS, Ateudjieu J, Jemea, Mbanya D. Accidental exposures to blood and body fluids among health care workers in a Referral Hospital of Cameroon. BMC Res Notes. 2016;9:94

16. Bayrakci B, Kesici S, Kendirli T, Kalkan G, Sari A, Tokmak N, Yilmaz G, Baloğlu 0 , Sencan I. Evaluation report of pediatric intensive care units in Turkey. Turk J Med Sci. 2014;44:1073-86.

17. Sevinç $S$, Türkmen E, IIlhan M. The Nursing Workforce in Critical Care Units in University and Private Hospitals in Turkey. Yoğun Bakım Derg. 2014;5:5-10.

18. Marković-Denić L, Branković M, Maksimović N, Jovanović B, Petrović I, Simić $\mathrm{M}$, Lesić A. Occupational exposures to blood and body fluids among health care workers at university hospitals. Srp Arh Celok Lek. 2013;141:789-93.

19. Tarantola A, Abiteboul D, Rachline A. Infection risks following accidental exposure to blood or body fluids in health care workers: a review of pathogens transmitted in published cases. Am J Infect Control. 2006;34:367-75.

20. Schmid K, Schwager C, Drexler H. Needlestick injuries and other occupational exposures to body fluids amongst employees and medical students of a German university: incidence and follow-up. J Hosp Infect. 2007;65:124-30.

21. Colombo $C$, Ledergerber $F$, Zysset $F$, Francioli $P$, Cavassini $M$, Blanchet $C L$, Ruef C. Exposition au risque infectieux VIH, VHB et VHC chez le personel des établissements de soins en Suisse de 2001 à fin juin 2008. BAG Bull 2010;3:36-42.

22. Özmert EN. Progress in the national immunization practices in the world and in Turkey. Çocuk Sağlığı ve Hastalıkları Dergisi 2008;51:168-75.

23. Hutin Y, Hauri A, Chiarello L, Catlin M, Stilwell B, Ghebrehiwet T, Garner J; Injection Safety Best Practices Development Group. Injection safety best practices development group-best infection control practices for intradermal, subcutaneous and intramuscular needle injections. Bull World Health Organ. 2003;81:491-500.

24. Gürün H, Aker A, Mokan L, Kalıntaş E, Demir A, Aydoslu ÇK, Daşçı Ö, Shatrì Y, Hıdıroğlu S, Save D. İstanbul'da İlkokul Öğrencilerinin Aşılanma Durumları ve Ebeveynlerinin Aşı Hakkındaki Düşünceleri. Halk Sağlığı Etkinlikleri, 19. Ulusal Halk Sağlığı Kongresi. 2017

25. WHO. Available date: 03.08.2017, Available from: http://apps.who.int/ immunization_monitoring/globalsummary/incidences?c=TUR 